\title{
C-Met Inhibitor AL2846
}

National Cancer Institute

\section{Source}

National Cancer Institute. c-Met Inhibitor AL2846. NCI Thesaurus. Code C129314.

An orally bioavailable small molecule inhibitor of the oncoprotein c-Met (hepatocyte growth factor receptor; HGFR), with potential antineoplastic activity. Upon oral administration AL2846 targets and binds to the c-Met protein, prevents c-Met phosphorylation and disrupts c-Met-dependent signal transduction pathways. This may induce cell death in tumor cells overexpressing c-Met protein or expressing constitutively activated c-Met protein. c-Met protein is overexpressed or mutated in many tumor cell types and plays key roles in tumor cell proliferation, survival, invasion, metastasis, and tumor angiogenesis. 